\title{
ON BEING A BIRD IN THE ARCTIC
}

\author{
GRAINGER HUNT \\ The Peregrine Fund, 5668 West Flying Hawk Lane, Boise, ID 83709, USA \\ E-mail: grainger@peregrinefund.org
}

\begin{abstract}
Gyrfalcon (Falco rusticolus) and ptarmigan populations extend to Earth's northernmost landmasses, among the coldest and driest regions of the world. Daily maximum temperatures when Gyrfalcons are incubating are well below freezing, followed by a short, intense burst of primary productivity making life possible in the balance. The relative simplicity of the tundra landscape and its biota underlies various forms of population instability, not unlike those associated with the classic experiments used to establish the basic principles of population dynamics theory. As natural demonstrations of those experiments, populations of most birds and mammals fluctuate in the Arctic, and nomadism among predators is a widespread adaptive response. In some regions the relationship of Gyrfalcons and ptarmigan appears to qualify as an exclusive interaction in a simple system. However, Gyrfalcons are largely cliff-dependent, range over vast areas, and their diets often vary among geographic locales and during the course of the year, so their relationship with ptarmigan is not always straightforward. Of potential future impact is an undercurrent of parasites and pathogens whose life history traits are responding to Arctic warming. As science, the manifestations of climate change can be regarded as a suite of input adjustments applied to a longterm ecological experiment with Gyrfalcons and ptarmigan, rich with replicates in the form of isolated study areas within the circumpolar distribution. Ideally, the scientists involved will, to the benefit of conservation, come to resolve and disseminate the implications of that experiment, even in its beginnings. Received 17 January 2011, accepted 31 May 2011.
\end{abstract}

Hunt, G. 2011. On being a bird in the Arctic. Pages 27-32 in R. T. Watson, T. J. Cade, M. Fuller, G. Hunt, and E. Potapov (Eds.). Gyrfalcons and Ptarmigan in a Changing World, Volume I. The Peregrine Fund, Boise, Idaho, USA. http://dx.doi.org/10.4080/gpcw.2011.0103

Key words: Gyrfalcon, Falco rusticolus, Rock Ptarmigan, Lagopus muta, Willow Ptarmigan, Lagopus lagopus, climate change, avian parasites, Snow Bunting, Plectrophenax nivalis, population regulation.

\section{Perspective}

GyRFALCONS (FALCO RUSTICOLUS) and Rock Ptarmigan (Lagopus muta) breed as far north as Ellesmere Island and northern Greenland at latitudes approaching 82 degrees. These most northerly terrestrial environments are among the coldest and driest on earth. In April and
May, when Gyrfalcons are incubating, daily maximum temperatures remain well below freezing, followed by a brief but intense photosynthetic bloom before the abrupt return of cold, stormy weather. Such environments preclude all but the hardiest of species and those specifically adapted. 
The structure of the tundra landscape and the spectrum of its biota are relatively simple, and simplicity is the stuff of scientific experiment. One might therefore expect high arctic birdlife to reveal the same kinds of responses and relationships to simplicity as those apparent in the classic laboratory experiments that established the core principles of population dynamics in the mid-20 ${ }^{\text {th }}$ Century. The designs of these experiments were simple in the extreme - typically a volume containing a primary food base and populated by two invertebrate species that either competed for a resource or interacted as predator and prey.

Gyrfalcons and ptarmigan in the simplicity of the tundra might be considered a naturallyoccurring avian parallel, and we are reminded of Carl Huffaker's studies in the 1950s of two species of mites - predator and prey - inhabiting trays of oranges upon which the former grazed (Huffaker 1958). By subtly manipulating single aspects of the experimental landscape, he was able to isolate the factors influencing stability in both populations. When he released the prey mites without their predator, their populations rather quickly exploded, ate the hairs off all the oranges despite their periodic renewal, and summarily starved. Adding the predator produced the beginning of an oscillation, but all too soon, the predators ate all their prey and perished. But when Huffaker made habitat structure a bit more complicated, his populations of predators and prey began cycling - not for long, alas, but long enough for him to demonstrate some core principles that still apply to predator-prey dynamics in natural systems: the role of environmental heterogeneity, dispersal, and the idea of the metapopulation.

As expected, small and medium-sized high arctic mammals - for example, lemmings, hares, weasels, and foxes-show population oscillations of somewhat predictable amplitude and periodicity, and those that display them often reveal causal interrelationships between predator and prey numbers (Hanski et al.
2001). But nature does not often demonstrate the demographic interaction of two species to the exclusion of all others (see Gilg et al. 2006), and a variety of factors may underlie coexistence. Among high arctic possibilities are multiple predators and multiple prey, nomadism, the irregularity of extreme weather, density-feedback from pathogens and parasites, and the presence of spatial heterogeneity influencing one or both populations.

Gyrfalcons and ptarmigan appear to interact most closely in environments where ptarmigan are virtually the sole prey (Nielsen 2003), whereas the relationship diminishes in those areas where Gyrfalcon diets are more diverse (Booms et al. 2008, Selas and Kalas 2007). Ptarmigan nevertheless cycle even in situations where there are no Gyrfalcons, and the factors reportedly influencing those oscillations are several (see New et al. 2009). Meanwhile, the Gyrfalcon is not a species that can breed anywhere there are ptarmigan, one reason being the requirement of open habitat structure suitable for hunting them. Moreover, Gyrfalcons require elevated structures that protect their nests from ground predators, and these structures-cliff ledges or the tree-nests of other raptors - may be uncommon, even rare in the tundra landscape, and territoriality further reduces the availability of sites when they are clustered within a single defended area. Habitat specificity of foraging and nesting Gyrfalcons thus restricts their distribution and consequent impact upon ptarmigan populations (see Zub et al. 2008 for a mammalian example).

All other things being equal, if prey numbers were to remain somewhat stable, a Gyrfalcon population would reach a comparably stable equilibrium based on the number of serviceable breeding locations, and might contain a reservoir of nonbreeding adults (floaters) that would buffer the breeding segment against loss (Hunt 1998). This is the case with temperate zone Peregrine Falcons ( $F$. peregrinus) whose high diversity of diet can be expected to compensate for the instability of a few of its components. 
With the dietary specialization of Gyrfalcons, it is far more certain that changes in the density of a single prey species will impact reproduction and even the year-to-year serviceability of breeding sites. In years of inadequate food, one might expect Gyrfalcons, rather than starving on location, to abandon their territories and move to places where food is more available in the vastness of undifferentiated tundra or seacoast, an option that further confounds the idea of a direct numerical response to prey numbers (see Selas and Kalas 2007).

Now, let us consider the Snow Bunting (Plectrophenax nivalis), a species showing some interesting similarities with Gyrfalcons, and some instructive differences. The males of this circumpolar passerine arrive on the high arctic tundra in April, 3-4 weeks before the arrival of the females, when temperatures never rise above freezing, and even the warmest daytime temperatures can be minus $20-30{ }^{\circ} \mathrm{C}$ (Meltofte 1983). Like the Gyrfalcon, this species nests in rocky recesses, and these may be rare in some areas such that nesting distribution is irregular and independent of population numbers beyond a certain point. Those male Snow Buntings that arrive first evidently do so in competition for the best nesting spots for thermoregulation and proximity to food, the latter then solely comprising those seed spikes stripped of snow by raging spring storms. The females eventually place their nests deep within the rock, averaging $27 \mathrm{~cm}$ (and as much as $60 \mathrm{~cm}$ ) from the surface, presumably positioned to escape convective winds and the notice of weasels. She may remain within her crevice throughout most of the incubation period and is fed by the male (Meltofte 1983).

It is reported that virtually all female Snow Buntings attempt to breed each year, evidently despite the penalties associated with the default acceptance of poor quality sites (Meltofte 1983, Lyon and Montgomerie 1995). A near-equal ratio of adult and yearling males has been observed in the spring population, suggesting a high cost of reproduction. As in many other passerines, the low expectation of returning to breed in future years requires Snow Buntings to maximize their annual reproductive effort.

Gyrfalcons are also site dependent and may jostle for high-quality sites, but unlike Snow Buntings, Gyrfalcons are potentially long-lived (Cade et al. 1998). Annual breeding is accordingly facultative and dependent upon prey numbers (see Potopov and Sale 2005 for review). Gyrfalcons forego breeding and even territory occupancy in years of low prey abundance, and one presumes that they achieve greater lifetime reproductive success by doing so. The ability of a pair of Gyrfalcons to subsist through a prey crash, either by staying put or by moving to a more favorable area, is largely unproven, but if true, reproduction rather than mortality is the life history trait that responds to ptarmigan cycles, and most strongly in the absence of buffering by alternative prey. Years of prey scarcity and abundance modulate Gyrfalcon population size by varying the serial representation of annual cohorts within the age structure of the population. The extent to which these modulations impact floater numbers is unknown, and it is conceivable that the floating segment is lost altogether in some years. With established territories becoming unoccupied in years of prey diminution, therefore, one cannot be certain whether vacancies equate to the deaths of occupants or to their movement to more favorable circumstances. Nomadic movement and migration carry the potential cost of competition for territory ownership in spring, but remaining where food is scarce risks confrontation with competitors in stronger condition returning from prey-rich wintering areas.

Parasites and pathogens may add yet another confounding dimension to our understanding of Gyrfalcons and ptarmigan populations. Gyrfalcons brought to temperate regions by falconers show susceptibility to a variety of microorganisms (Booms et al. 2008), and warming may bring some of them northward 
(see Kutz et al. 2009). Abundances of several endoparasites, including the cestode Hymenolepis microps, were associated with reduced population growth rates and lower body condition among Willow Ptarmigan (Lagopus lagopus) in northern Norway (Holmstad et al. 2005). Studies of ptarmigan parasite loads have revealed a wide variety of blood parasites, including those transferred by mosquito vectors (Holmstad et al. 2003), the prevalence of which is expected to increase with warming. There is evidence even now of increased outbreaks of mosquito-borne filaroid nematodes among ungulates in subarctic Fennoscandia, and with apparent demographic consequences (Laaksonen et al. 2010). Mosquito habitats may multiply with increased rain and melting permafrost, and the lengthening summers may allow greater development and plasticity within the life cycles of many parasites and pathogens, promoting their prevalence, transmission, and the diversity and longevity of their vectors (see Laaksonen et al. 2010). Bennett et al. (1992) reported that blood parasites were "...virtually absent in bird species nesting in the open tundra," with the inference that vectors were lacking, and one wonders what their predicted arrival may portend for avian populations.

In summary, these examples of ecological factors in the Arctic are inconsistent with the idea that Gyrfalcon and ptarmigan interactions alone explain their population dynamics. The two are not the stuff of Huffaker's simple experiments, and yet those experiments still seem a good place to begin one's analysis. Climate change is altering the Arctic landscape, and some scientists even predict that tundra will be eliminated through the gradual encroachment of woody plants (Tape et al. 2006, Forbes et al. 2010). Such transformation may benefit Willow Ptarmigan at least temporarily along the way, but it may make them more difficult for Gyrfalcons to catch. Perhaps one way of understanding and anticipating the processes that may alter the life histories of these species is to study them closely in areas of shrub advancement and along the tundrataiga ecotone. Such an approach could be one of several that examine predicted changes as input variables in a predator-prey experiment on a grand scale, considering the variety of study replicates and variants even now apparent in the pan-Arctic distribution of ptarmigan and Gyrfalcons. Given the observed rapidity of change in arctic environments, beginning the analysis now may benefit conservation in helping society take better, more immediate measure of the implications.

\section{Literature Cited}

Bennett, G. F., R. Montgomerie, and G. SEUTIN. 1992. Scarcity of haematozoa in birds breeding on the Arctic tundra of North America. Condor 94:289-292.

Booms, T. L., T. J. CAde, ANd N. J. Clum. 2008. Gyrfalcon (Falco rusticolus). In A. Poole (Ed.). The Birds of North America Online. Ithaca: Cornell Lab of Ornithology; Retrieved from The Birds of North America Online database: http://bna.birds.cornell. edu/bna/species/114 http://dx.doi.org/10.2173/bna.114

Cade, T. J., P. Koskimies, And K. Nielson. 1998. Falco rusticolus Gyrfalcon. BWP Update, Journal of Birds of the Western Palearctic 2:1-25.

Forbes, B. C., M. M. FAuria, AND P. ZetterBERG. 2010. Russian Arctic warming and 'greening' are closely tracked by tundra shrub willows. Global Change Biology 16:1542-1554. http://dx.doi.org/10.1111/ j.1365-2486.2009.02047.x

Gilg, O., B. Sittler, B. Sabard, A. Hurstel, R. Sané, P. Delattre, and I. Hanski. 2006. Functional and numerical responses of four lemming predators in high arctic Greenland. Oikos 113:193-216.

HANSKi, I., H. HentTonen, E. Korpimaki, L. OKSANEN, AND P. TUIRCHIN. 2001. Smallrodent dynamics and predation. Ecology 82:1505-1520.

Holmstad, P. R., A. ANWAR, T. IEZHova, AND A. SKorping. 2003. Standard sampling 
techniques underestimate prevalence of avian hematozoa in Willow Ptarmigan (Lagopus lagopus). Journal of Wildlife Diseases 39:354-358.

Holmstad, P. R., P. J. Hudson, AND A. SKorPING. 2005. The influence of a parasite community on the dynamics of a host population: A longitudinal study on Willow Ptarmigan and their parasites. Oikos 111:377-391.

HufFAKer, C. B. 1958. Experimental studies on predation: Dispersion factors and predator-prey oscillations. Hilgardia 27:343-383.

HunT, W. G. 1998. Raptor floaters at Moffat's equilibrium. Oikos 82:191-197.

Kutz, S. J., E. J. Jenkins, A. M. Veitch, J. Ducroce, L. Polley, B. Elkin, and S. LAIR. 2009. The Arctic as a model for anticipating, preventing, and mitigating climate change impacts on host-parasite interactions. Veterinary Parasitology 163:217228. http://dx.doi.org/10.1016/j.vetpar. 2009.06.008

Laaksonen, S., J. Pusenius, J. Kumpula, A. Venalainen, R. Kortet, A. OKsanen, And E. Hoberg. 2010. Climate change promotes the emergence disease outbreaks of filaroid nematodes. EcoHealth 7:7-13.

LyON, B., AND R. MONTGOMERIE. 1995. Snow Bunting (Plectrophenax nivalis). In A. Poole (Ed.). The Birds of North America Online. Ithaca: Cornell Lab of Ornithology; Retrieved from The Birds of North America Online database: http://bna.birds.cornell. edu/bna/species $/ 198$

http://dx.doi.org/10.2173/bna.198
Meltofte, H. 1983. Arrival and pre-nesting period of the Snow Bunting Plectrophenax nivalis in East Greenland. Polar Research 1:185-198.

New, L. F., J. Matthiopoulos, S. Redpath, AND S. T. BuCKLAND. 2009. Fitting models of multiple hypotheses to partial population data: Investigating the causes of cycles in Red Grouse. American Naturalist 174:399-412.

NiELSEN, Ó.K. 2003. The impact of food availability on Gyrfalcon (Falco rusticolus) diet and timing of breeding. Pages 283-302 in D. B. A. Thompson, S. M. Redpath, A. H. Fielding, M. Marquiss, and C. A. Galbraith (Eds.). Birds of Prey in a Changing Environment. Scottish Natural Heritage, Joint Nature Conservation Committee, British Ornithologists' Union. The Stationery Office Ltd, Edinburgh, UK.

Potapov, E., ANd R. SAle. 2005. The Gyrfalcon. T. \& A. D. Poyser, London, UK.

SElas, V., AND A. Kalas. 2007. Territory occupancy rate of Gyrfalcon and Goshawk: No evidence of delayed numerical response to grouse numbers. Oecologia 153:555-561.

TAPe, K., M. Strum, and C. Racine. 2006. The evidence for shrub expansion in Northern Alaska and the Pan-Arctic. Global Change Biology 12:686-702. http://dx.doi. org/10.1111/j.1365-2486.2006.01128.x

Zub, K., L. SÖNNICHSEN, AND P. A. SZAFRAŃSKA. 2008. Habitat requirements of weasels Mustela nivalis constrain their impact on prey populations in complex ecosystems of the temperate zone. Oecologia 157:571-582. 
- HUNT - 